\title{
Effect of wheat distillers dried grains with soluble on performance, carcass characteristics and immunity of broiler chicks
}

\author{
M. Sharyari, A. Emadinia*, A. Davoodi, A. Salehi, G. Jalili
}

Research and Development Center, Davoodi Commercial Group, Isfahan, Iran

*Corresponding author:E-mail- aemadinia@yahoo.com

Telephone number: (+98) 9133051543; Fax: (+98) 31132306597

Journal of Livestock Science (ISSN online 2277-6214) 11: 54-59

Received on 30/11/2019; Accepted on 24/2/2020

doi. 10.33259/JLivestSci.2020.54-59

\begin{abstract}
The study was performed to evaluate the effects of wheat- distillers dried grain with soluble (DDGS) levels on performance, carcass- characteristics, lymphoid organs and antibody titer against Avian Influenza and Newcastle Disease. A total of 144 day old broiler chicks (Ross 308) were randomly distributed between 3 treatments with 4 replicates and 12 chicks per each replication. The treatments included: control diet without wheat DDGS (A); $3,4,6$ and 7\% wheat-DDGS in starter, grower and finisher 1 and 2 phases respectively (B); 6, 8, 12 and 14\% wheat-DDGS in starter, grower and finisher 1 and 2 phases respectively (C). Results showed that body weight at $50 \mathrm{~d}$, daily weight gain at 25-39, 39-50 and 9-50 days significantly decreased $C$ treatment $(P<0.05)$. The feed intake at $16-25 \mathrm{~d}$ significantly decreased by $\mathrm{C}$ treatment $(\mathrm{P}<0.05)$. The feed conversion ratio at $25-39,39-50$ and $9-50$ days in $\mathrm{C}$ treatment significantly decreased compare to control group $(\mathrm{P}<0.05)$. The percentage of carcass, heart, gizzard and ileum significantly decreased by $\mathrm{C}$ treatment $(\mathrm{P}<0.05)$. Also, jejunum weight percentage in $\mathrm{B}$ and $\mathrm{C}$ treatments compare to control group significantly increased $(\mathrm{P}<0.05)$. As a conclusion, using incremental levels of wheatDDGS (3, 4, 6 and 7\%) in starter, grower, finisher 1 and 2 phases did not make significant change on broilers; performance. On the other hand, inclusion high levels of wheat-DDGS (12 and 14\%) in finisher 1 and 2 phases decreased broilers' performance $(\mathrm{P}<0.05)$.
\end{abstract}

Keywords: Broiler; Wheat-DDGS; Performance; Carcass; Immunity 


\section{Introduction}

One of the by-products in ethanol and beverage production process is distillers dried grains with soluble (DDGS) which is produced after starch fermentation of cereals (Cozannet et al., 2010). In poultry industry, the information about chemical composition and nutritional values of DDGS in poultry nutrition is limited especially for wheat-DDGS, because a few number of studies have been performed (Widyaratne and Zijlstra, 2007).

After the fermentation process of corn and wheat to produce ethanol and fat extraction by centrifuge, the obtained by-product is dried distiller grain with soluble which can be a protein ingredient in poultry diet. Assessment of how much corn or wheat DDGS can be effectively fed to poultry varies (Shim et al., 2011). Lumpkins et al (2004) deduced that starter, grower and finisher diets of broilers should not contain more than 12 or $15 \%$ DDGS. Although, wheat DDGS contain high level of protein, there are concerns about the level and digestibility of amino acid, especially lysine (Cozannet et al., 2010; Bolarinwa and Adeola, 2012). Parsones et al (1983) found that up to $40 \%$ soy protein in broilers diet can be replace with DDGS, if the lysine level provided according to requirement. Waldroup et al (1981) reported that if metabolisable energy level provided constantly, the DDGS can included in broilers diet up to $25 \%$ without negative effect on body weight and feed conversion ratio. The objective of present study was to determine the effects of different levels of wheat DDGS on growth performance of chicks.

\section{Materials and methods}

The experiment was conducted at the experimental farm of Davoodi Commercial Group, with longitude 51.78, latitude 32.65 and altitude 1557. A total of 144 broiler chicks (Ross 308) were used in this experiment and were randomly allocated to 3 treatments with 4 replicates and 12 chicks per each replicate. The feed and water were provided by a hanging feeder and nipple drinker in each pen. Feed and water were provided ad libitum till the end of the trial. Body weight (BW), feed intake (FI), daily weight gain (DWG) and feed conversion ratio (FCR) were determined for each replicate at 15,28, 43 and 50 days of age. The experiment was started from 9 days old. The 4 experimental periods included: starter (9-16 d), grower (17-25 d), finisher one (26-39 d), and finisher two (44-50 d).

The experimental period lasted 50 days. At first broiler received commercial diet till 8 d, then 4 experimental periods included of: starter (9-16 d), grower (17-25 d), finisher one (26-39 d), finisher two (44-50 d). Composition and calculated energy and nutrient content of diets from day 8 to 50 are presented in Tables 1 . Experimental diets as follow: control diet without wheat-DDGS (A); diets with incremental levels of 3, 4, 6 and 7\% wheat-DDGS in starter, grower, finisher 1 and 2, respectively (B); diets with incremental levels of 6, 8, 12 and $14 \%$ wheat-DDGS starter, grower, finisher 1 and 2, respectively $(\mathrm{C})$.

At 7 days all broiler chicks were intramuscularly immunized with a killed vaccine against Newcastle and Avian Influenza Viruses. The blood sample was taken from wing vein of two birds per each replicate. The blood serum was separated and antibody titer against Newcastle and Influenza Viruses were determined by haemaglutination inhibition (HI) test and expressed as the logarithm base 2 (Shahryari et al., 2019). The immune test was done at the Arian Dom Laboratory (an authorized with Iran Veterinary Organization).

At 50 days of age, two birds per replicate with body weight similar to the mean body weight of each pen were selected, slaughtered and after that carcass characteristics and lymphoid organs (spleen and bursa of fabricius) were collected, weighed and expressed as a percentage of live body weight.

Statistical analysis

Analysis was performed with the SAS software, using the general linear model procedure. Significant differences $(\mathrm{P}<0.05)$ among treatment means were defined using LSD test.

\section{Results and Discussion}

\section{Growth performance}

Effects of experimental diets on growth performance of broiler chickens is reported in Table 2. Inclusion low levels of wheat-DDGS (3, 4, 6 and 7\% in starter, grower and finisher 1 and 2 periods, respectively) had no effect on performance parameters such as body weight, daily weight gain, feed intake and feed conversion ratio of broiler chicks. According to low price of wheat-DDGS than to corn and soybean meal and no negative effect of incremental levels of wheat-DDGS (3, 4, 6 and 7\% in starter, grower, finisher 1 and 2 periods, respectively) on growth performance of broiler chicks can substitute corn and soybean meal with wheat-DDGS.

In starter phase (9-16 d) incremental levels of wheat DDGS $(6,8,12$ and $14 \%)$ had no significant effect on BW, DWG and FCR of broiler chicks. In starter, grower, finisher 1 and 2 phases the FI of broilers significantly decreased by incremental levels of DDGS $(\mathrm{P}<0.05)$, but there was no significant difference between $\mathrm{BW}, \mathrm{DWG}$ and FCR of broilers. In finisher 1 and 2 phases the FI was not affected by experimental diet, but BW at 50 day, DWG and FCR in finisher 1 and 2 phases adversely affected by incremental levels of wheat DDGS (6, 8, 12 and 14\%) $(\mathrm{P}<0.05)$. In overall rearing phase the FI was not affected by experimental diets, the DWG and FCR significantly decreased by $6,8,12$ and $14 \%$ wheat DDGS. 
Table 1. Ingredient and composition of the starter diet

\begin{tabular}{|c|c|c|c|c|c|c|c|c|c|c|c|c|}
\hline \multirow{2}{*}{ Diet composition } & \multicolumn{3}{|c|}{ Starter } & \multicolumn{3}{|c|}{ Grower } & \multicolumn{3}{|c|}{ Finisher 1} & \multicolumn{3}{|c|}{ Finisher 2} \\
\hline & $\mathrm{A}$ & $\mathrm{B}$ & $\mathrm{C}$ & A & $\mathrm{B}$ & $\mathrm{C}$ & $\mathrm{A}$ & $\mathrm{B}$ & $\mathrm{C}$ & $\mathrm{A}$ & $\mathrm{B}$ & $\mathrm{C}$ \\
\hline Corn seed & 50.65 & 49.1 & 48 & 52.3 & $\begin{array}{ll}50.8 \\
\end{array}$ & $\begin{array}{l}49.2 \\
\end{array}$ & 56.5 & 54.7 & 52.9 & 57.7 & 55.4 & 53.3 \\
\hline Soybean meal & 24 & 22.5 & 20.5 & 22.8 & 20.3 & 17.8 & 18.6 & 14.4 & 10.2 & 15.5 & 10.7 & 5.9 \\
\hline Oil & 0.9 & 1 & 1 & 1 & 1 & 1 & 1.3 & 1.3 & 1.3 & 1.5 & 1.5 & 1.5 \\
\hline Salt & 0.2 & 0.2 & 0.2 & 0.2 & 0.2 & 0.2 & 0.2 & 0.2 & 0.1 & 0.25 & 0.2 & 0.1 \\
\hline MCP & 1.05 & 1 & 1 & 0.85 & 0.81 & 0.79 & 0.73 & 0.67 & 0.62 & 0.55 & 0.5 & 0.44 \\
\hline $\mathrm{CaCO}_{3}$ & 1.715 & 1.695 & 1.755 & 1.585 & 1.585 & 1.645 & 1.45 & 1.46 & 1.49 & 1.36 & 1.45 & 1.4 \\
\hline Lysine & 0.39 & 0.42 & 0.46 & 0.33 & 0.39 & 0.44 & 0.3 & 0.39 & 0.48 & 0.31 & 0.42 & 0.52 \\
\hline Methionine & 0.28 & 0.27 & 0.26 & 0.2 & $\begin{array}{l}0.19 \\
\end{array}$ & $\begin{array}{l}0.19 \\
\end{array}$ & 0.2 & 0.18 & 0.18 & 0.16 & 0.15 & 0.14 \\
\hline Threonine & 0.13 & 0.14 & 0.15 & 0.1 & 0.11 & 0.13 & 0.07 & 0.09 & 0.12 & 0.06 & 0.09 & 0.11 \\
\hline $\mathrm{NaHCO}_{3}$ & 0.13 & 0.13 & 0.13 & 0.13 & 0.13 & 0.13 & 0.15 & 0.15 & 0.15 & 0.15 & 0.15 & 0.15 \\
\hline Mineral premix ${ }^{1}$ & 0.14 & 0.14 & 0.14 & 0.12 & 0.12 & 0.12 & 0.1 & 0.1 & 0.1 & 0.1 & 0.1 & 0.1 \\
\hline Vitamin premix ${ }^{2}$ & 0.14 & 0.14 & 0.14 & 0.12 & 0.12 & 0.12 & 0.1 & 0.1 & 0.1 & 0.1 & 0.1 & 0.1 \\
\hline Choline chloride & 0.05 & 0.05 & 0.05 & 0.05 & 0.05 & 0.05 & 0.05 & 0.05 & 0.05 & 0.05 & 0.05 & 0.05 \\
\hline Toxin binder & 0.2 & 0.2 & 0.2 & 0.2 & 0.2 & 0.2 & 0.2 & 0.2 & 0.2 & 0.2 & 0.2 & 0.2 \\
\hline Canola meal & 6 & 6 & 6 & 6 & 6 & 6 & 7 & 7 & 7 & 9 & 9 & 9 \\
\hline DDGS & 0 & 3 & 6 & 0 & 4 & 8 & 0 & 6 & 12 & 0 & 7 & 14 \\
\hline Sesame meal & 2 & 2 & 2 & 2 & 2 & 2 & 2 & 2 & 2 & 2 & 2 & 2 \\
\hline Corn gluten & 2 & 2 & 2 & 2 & 2 & 2 & 1 & 1 & 1 & 1 & 1 & 1 \\
\hline Wheat & 10 & 10 & 10 & 10 & 10 & 10 & 10 & 10 & 10 & 10 & 10 & 10 \\
\hline Phytase & 0.01 & 0.01 & 0.01 & 0.01 & 0.01 & 0.01 & 0.01 & 0.01 & 0.01 & 0.01 & 0.01 & 0.01 \\
\hline Multi enzyme & 0.005 & 0.005 & 0.005 & 0.005 & 0.005 & 0.005 & 0.005 & 0.005 & 0.005 & 0.005 & 0.005 & 0.005 \\
\hline Metabolizable energy $(\mathrm{Kcal} / \mathrm{Kg})$ & 2912 & 2913 & 2910 & 2942 & 2941 & 2936 & 3003 & 3003 & 3002 & 3031 & 3026 & 3028 \\
\hline Crude protein $\%$ & 21.06 & 21.16 & 21.10 & 20.52 & 20.51 & 20.49 & 18.0 & 18.0 & 18.0 & 17.43 & 17.47 & 17.51 \\
\hline Digestible lysine\% & 1.15 & 1.15 & 1.15 & 1.08 & 1.08 & 1.08 & 0.96 & 0.96 & 0.96 & 0.93 & 0.93 & 0.93 \\
\hline Digestible Met+Cys\% & 0.9 & 0.9 & 0.9 & 0.82 & 0.82 & 0.82 & 0.77 & 0.77 & 0.77 & 0.73 & 0.73 & 0.73 \\
\hline Digestible Thr\% & 0.78 & 0.78 & 0.78 & 0.73 & 0.73 & 0.73 & 0.64 & 0.64 & 0.64 & 0.61 & 0.61 & 0.61 \\
\hline Calcium\% & 0.96 & 0.96 & 0.96 & 0.87 & 0.87 & 0.87 & 0.8 & 0.8 & 0.8 & 0.74 & 0.74 & 0.74 \\
\hline Available phosphorous $\%$ & 0.48 & 0.48 & 0.48 & 0.435 & 0.435 & 0.435 & 0.39 & 0.39 & 0.39 & 0.35 & 0.35 & 0.35 \\
\hline $\mathrm{Na} \%$ & 0.17 & 0.17 & 0.17 & 0.17 & 0.17 & 0.17 & 0.18 & 0.18 & 0.18 & 0.19 & 0.19 & 0.19 \\
\hline $\mathrm{Cl} \%$ & 0.21 & 0.21 & 0.21 & 0.21 & 0.21 & 0.21 & 0.21 & 0.21 & 0.21 & 0.21 & 0.21 & 0.21 \\
\hline
\end{tabular}

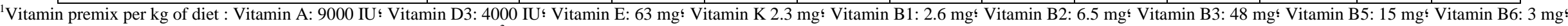

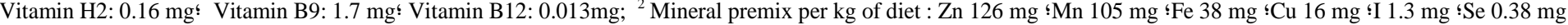


Table 2. Effect of wheat DDGS levels on performance of broiler chicks

\begin{tabular}{|c|c|c|c|c|}
\hline Items & $\mathbf{A}$ & B & $\mathbf{C}$ & P-value \\
\hline \multicolumn{5}{|l|}{$9-16 \mathrm{~d}$} \\
\hline FI & $51.44^{\mathrm{a}} \pm 0.32$ & $52.01^{\mathrm{a}} \pm 0.47$ & $51.69^{\mathrm{a}} \pm 0.36$ & $\mathrm{P}<0.59$ \\
\hline BW & $518.65^{\mathrm{a}} \pm 4.30$ & $530.00^{\mathrm{a}} \pm 4.51$ & $522.00^{\mathrm{a}} \pm 2.43$ & $\mathrm{P}<0.14$ \\
\hline DWG & $47.77^{\mathrm{a}} \pm 0.22$ & $48.57^{\mathrm{a}} \pm 0.64$ & $47.42^{\mathrm{a}} \pm 0.34$ & $\mathrm{P}<0.21$ \\
\hline FCR & $1.06^{\mathrm{a}} \pm 0.008$ & $1.07^{\mathrm{a}} \pm 0.009$ & $1.07^{\mathrm{a}} \pm 0.007$ & $\mathrm{P}<0.43$ \\
\hline \multicolumn{5}{|l|}{$16-25 \mathrm{~d}$} \\
\hline FI & $93.71^{\mathrm{a}} \pm 0.70$ & $93.97^{\mathrm{a}} \pm 1.02$ & $90.92^{\mathrm{b}} \pm 0.74$ & $\mathrm{P}<0.04$ \\
\hline $\mathrm{BW}$ & $1096.20^{\mathrm{a}} \pm 12.33$ & $1099.43^{\mathrm{a}} \pm 2.25$ & $1107.20^{\mathrm{a}} \pm 13.72$ & $\mathrm{P}<0.76$ \\
\hline DWG & $64.17^{\mathrm{a}} \pm 1.66$ & $63.26^{\mathrm{a}} \pm 0.52$ & $65.02^{\mathrm{a}} \pm 1.43$ & $\mathrm{P}<0.64$ \\
\hline FCR & $1.46^{\mathrm{a}} \pm 0.03$ & $1.48^{\mathrm{a}} \pm 0.01$ & $1.40^{\mathrm{a}} \pm 0.03$ & $\mathrm{P}<0.19$ \\
\hline \multicolumn{5}{|l|}{$25-39 d$} \\
\hline FI & $142.58^{\mathrm{a}} \pm 0.39$ & $141.74^{\mathrm{a}} \pm 0.20$ & $142.31^{\mathrm{a}} \pm 0.74$ & $\mathrm{P}<0.49$ \\
\hline $\mathrm{BW}$ & $2169.6^{\mathrm{a}} \pm 21.80$ & $2160.0^{\mathrm{a}} \pm 4.28$ & $2137.8^{\mathrm{a}} \pm 10.04$ & $\mathrm{P}<0.29$ \\
\hline DWG & $76.67^{\mathrm{a}} \pm 0.85$ & $75.75^{\mathrm{ab}} \pm 0.35$ & $73.61^{\mathrm{b}} \pm 0.78$ & $\mathrm{P}<0.02$ \\
\hline FCR & $1.86^{\mathrm{b}} \pm 0.02$ & $1.87^{\mathrm{ab}} \pm 0.01$ & $1.94^{\mathrm{a}} \pm 0.02$ & $\mathrm{P}<0.05$ \\
\hline \multicolumn{5}{|l|}{$39-50 \mathrm{~d}$} \\
\hline FI & $170.23^{\mathrm{a}} \pm 2.42$ & $174.58^{\mathrm{a}} \pm 0.64$ & $173.30^{\mathrm{a}} \pm 0.73$ & $\mathrm{P}<0.15$ \\
\hline BW & $3092.40^{\mathrm{a}} \pm 22.80$ & $3113.40^{\mathrm{a}} \pm 22.80$ & $2962.04^{\mathrm{b}} \pm 16.66$ & $\mathrm{P}<0.002$ \\
\hline DWG & $83.89^{\mathrm{a}} \pm 2.54$ & $86.63^{\mathrm{a}} \pm 2.97$ & $74.93^{\mathrm{b}} \pm 2.31$ & $\mathrm{P}<0.02$ \\
\hline FCR & $2.03^{\mathrm{b}} \pm 0.06$ & $2.02^{\mathrm{b}} \pm 0.07$ & $2.32^{\mathrm{a}} \pm 0.06$ & $\mathrm{P}<0.01$ \\
\hline \multicolumn{5}{|l|}{$9-50$} \\
\hline FI & $119.97^{\mathrm{a}} \pm 0.73$ & $120.54^{\mathrm{a}} \pm 0.29$ & $119.69^{\mathrm{a}} \pm 0.36$ & $\mathrm{P}<0.49$ \\
\hline DWG & $69.10^{\mathrm{a}} \pm 0.54$ & $69.59^{\mathrm{a}} \pm 0.82$ & $66.00^{\mathrm{b}} \pm 0.39$ & $\mathrm{p}<0.002$ \\
\hline FCR & $1.73^{\mathrm{b}} \pm 0.01$ & $1.73^{\mathrm{b}} \pm 0.02$ & $1.81^{\mathrm{a}} \pm 0.01$ & $\mathrm{P}<0.005$ \\
\hline
\end{tabular}

a-b Means within the row with no common superscripts differ significantly. A: Control diet without wheat DDGS; B: 3, 4, 6 and 7\% wheatDDGS in starter, grower, finisher 1 and 2, respectively. C: 6, 8, 12 and 14\% wheat-DDGS in starter, grower, finisher 1 and 2, respectively. FI: Feed intake; BW: Body weight; DWG: Daily weight gain; FCR: Feed conversion ratio.

Table 3. Effect of wheat DDGS levels on carcass characteristics of broiler chicks (Live wt. \%)

\begin{tabular}{|l|l|l|l|l|}
\hline Items & $\mathrm{A}$ & $\mathrm{B}$ & $\mathrm{C}$ & $\mathrm{P}$-value \\
\hline Carcass & $66.09^{\mathrm{a}} \pm 0.53$ & $66.60^{\mathrm{a}} \pm 0.18$ & $63.62^{\mathrm{b}} \pm 0.64$ & $\mathrm{P}<0.002$ \\
\hline Heart & $0.49^{\mathrm{b}} \pm 0.01$ & $0.48^{\mathrm{b}} \pm 0.01$ & $0.60^{\mathrm{a}} \pm 0.01$ & $\mathrm{P}<0.0002$ \\
\hline Liver & $1.74^{\mathrm{a}} \pm 0.04$ & $1.79^{\mathrm{a}} \pm 0.05$ & $1.85^{\mathrm{a}} \pm 0.02$ & $\mathrm{P}<0.18$ \\
\hline Pancreas & $0.15^{\mathrm{a}} \pm 0.02$ & $0.15^{\mathrm{a}} \pm 0.02$ & $0.16^{\mathrm{a}} \pm 0.02$ & $\mathrm{P}<0.96$ \\
\hline Proventriculus & $0.33^{\mathrm{a}} \pm 0.01$ & $0.36^{\mathrm{a}} \pm 0.02$ & $0.37^{\mathrm{a}} \pm 0.01$ & $\mathrm{P}<0.27$ \\
\hline Gizzard & $1.21^{\mathrm{b}} \pm 0.03$ & $1.35^{\mathrm{a}} \pm 0.05$ & $1.38^{\mathrm{a}} \pm 0.03$ & $\mathrm{P}<0.04$ \\
\hline Deudenum & $0.52^{\mathrm{a}} \pm 0.04$ & $0.54^{\mathrm{a}} \pm 0.03$ & $0.59^{\mathrm{a}} \pm 0.03$ & $\mathrm{P}<0.39$ \\
\hline Jejunum & $0.77^{\mathrm{b}} \pm 0.05$ & $1.02^{\mathrm{a}} \pm 0.06$ & $1.13^{\mathrm{a}} \pm 0.02$ & $\mathrm{P}<0.0009$ \\
\hline Ileum & $0.65^{\mathrm{b}} \pm 0.04$ & $0.72^{\mathrm{ab}} \pm 0.03$ & $0.86^{\mathrm{a}} \pm 0.06$ & $\mathrm{P}<0.03$ \\
\hline Cecum & $0.93^{\mathrm{a}} \pm 0.07$ & $0.94^{\mathrm{a}} \pm 0.07$ & $0.93^{\mathrm{a}} \pm 0.16$ & $\mathrm{P}<0.99$ \\
\hline Abdominal fat & $1.85^{\mathrm{a}} \pm 0.09$ & $1.93^{\mathrm{a}} \pm 0.04$ & $2.05^{\mathrm{a}} \pm 0.07$ & $\mathrm{P}<0.19$ \\
\hline
\end{tabular}

a-b Means within the row with no common superscripts differ significantly. A: Control diet without wheat DDGS; B: 3, 4, 6 and 7\% wheatDDGS in starter, grower, finisher 1 and 2, respectively. C: 6, 8, 12 and 14\% wheat-DDGS in starter, grower, finisher 1 and 2, respectively.

Table 4. Effect of wheat DDGS levels on antibody titer production against avian influenza and Newcastle diseases and lymphoid organs of broiler chicks

\begin{tabular}{|l|l|l|l|l|}
\hline \multirow{2}{*}{ Treatments } & \multicolumn{2}{|c|}{ Antibody titer } & \multicolumn{2}{c|}{$\begin{array}{c}\text { Lymphoid organs } \\
\text { (Live weight percentage) }\end{array}$} \\
\cline { 2 - 5 } & AI & ND & Spleen & Bursa of fabricus \\
\hline A & $5.42^{\mathrm{a}} \pm 0.29$ & $4.00^{\mathrm{a}} \pm 0.30$ & $0.12^{\mathrm{a}} \pm 0.00$ & $0.06^{\mathrm{a}} \pm 0.00$ \\
\hline $\mathrm{B}$ & $5.28^{\mathrm{a}} \pm 0.28$ & $4.00^{\mathrm{a}} \pm 0.30$ & $0.12^{\mathrm{a}} \pm 0.00$ & $0.06^{\mathrm{a}} \pm 0.01$ \\
\hline $\mathrm{C}$ & $5.57^{\mathrm{a}} \pm 0.20$ & $4.28^{\mathrm{a}} \pm 0.18$ & $0.11^{\mathrm{a}} \pm 0.01$ & $0.06^{\mathrm{a}} \pm 0.00$ \\
\hline P-value & $\mathrm{P}<0.75$ & $\mathrm{P}<0.7$ & $\mathrm{P}<0.80$ & $\mathrm{P}<0.99$ \\
\hline
\end{tabular}

a-b Means within the row with no common superscripts differ significantly. AI: Avian Influenza; ND: Newcastle Disease. A: Control diet without wheat DDGS; B: 3, 4, 6 and 7\% wheat-DDGS in starter, grower, finisher 1 and 2, respectively. C: $6,8,12$ and $14 \%$ wheat-DDGS in starter, grower, finisher 1 and 2, respectively.

Oryschak et al (2010) reported that inclusion of 5 and 10\% wheat DDGS in broilers diet had no significant effect on BW and DWG of broilers in different rearing phases, but FI and FCR of broilers at 28-42 d significantly decreased by $10 \%$ wheat DDGS $(\mathrm{P}<0.05)$. Therefore, they proposed that $10 \%$ wheat DDGS can be used in broilers diet without adverse effect on growth performance. The poor growth performance in broilers fed on diet containing high wheat DDGS can be because of low digestibility of branched chain amino acid and low lysine content.

According to mentioned issue, it can be concluded that till the wheat DDGS included in broilers diet lower than $10 \%$ (starter and grower phases) had no adverse effect on growth performance, but in finisher one and two phases 12 and 14\% wheat DDGS inclusion decreased growth performance. Oryschak et al (2010) and Lumpkins et al (2004) suggested that decrease broilers performance by using high DDGS is probably because of overestimation 
of lysine in DDGS that is cause to marginal shortage of this amino acid. Also, they suggested that 6\% DDGS in starter phase, 12 to $15 \%$ in grower and finisher phases is acceptable. Similar to obtained results, Wen et al (2013) reported that using 10\% DDGS with $200 \mathrm{mg} / \mathrm{kg}$ vitamin $\mathrm{E}$ in layer diet had no adverse effect on their production.

Lumpkins et al (2004) performed two experiments to evaluate new generation of DDGS in broilers diet. In first experiment two starter diets (high and low density) contain 0 and 15\% DDGS formulated. There was no significant difference between two levels of DDGS on broilers' growth performance. The broilers received diet low density and 15\% DDGS had low feed efficiency (gain/feed) in 7 and 14 days.

In second experiment the iso-caloric and iso-nitrogenous diet with $0,6,12$, and $18 \%$ DDGS formulated for starter, grower and finisher phases, respectively. The results showed no differences in performance and carcass characteristics of broilers, except that daily weight gain and feed conversion ratio of broilers at starter phase decreased by $18 \%$ DDGS $(\mathrm{P}<0.05)$.

Zhang et al (2013) showed that diets contain 20\% DDGS cause to decrease growth performance of broilers. Also, adding DDGS up to $10 \%$ of diet had no negative effect on growth performance, carcass characteristics and immune organs development of broilers (ICAR-CARI, 2015). In confirming to obtained results, Ibrahim et al (2008) stated that using 15\% DDGS in 12-35 days of broilers age had no significant effect on DWG, but the FCR significantly increased compare to control group $(\mathrm{P}<0.05)$. Also, they observed no significant difference in FCR of broilers fed on diet contain 5 and $10 \%$ compare to control group.

In contrast to results of present study, Lumpkins et al (2004) and Wang et al (2008) expressed that using $20 \%$ corn DDGS had no significant effect on broilers performance, although the discrepancy between results can be because of different DDGS sources. Another reason in broilers performance reduction might be because of $10 \%$ higher soluble NSP in wheat DDGS than other DDGS sources. The soluble NSP in wheat is more than corn (Hetland et al., 2004), so inclusion of wheat DDGS in diet cause to increase NSP content of diet. The difference in NSP content might be difference in wheat and corn DDGS usage.

Thacker and Widyaratne (2007) used 0,10, 15 and 20\% wheat DDGS in broilers diet, they observed no significant difference in DWG, FI and FCR of broilers; although, the growth performance of broilers received $20 \%$ wheat DDGS tend to decrease. Guney et al (2013) reported that corn DDGS inclusion up to $20 \%$ compare to diets based on corn-soybean meal had no negative effect on broilers performance. Olofintoye and Bolu (2013) observed that using 20\% corn DDGS in layer diet improved their production compare to control group.

\section{Carcass characteristics}

The effect of wheat-DDGS on carcass characteristics of broilers are presented in Table 3 . The 6, 8, 12 and $14 \%$ wheat-DDGS in starter, grower, finisher 1 and 2 phases respectively, significantly decreased carcass percentage, and significantly increased percentage weight of heart, gizzard, jejunum and ileum of broilers $(\mathrm{P}<0.05)$. Use of 3, 4, 6 and 7\% wheat-DDGS in starter, grower, finisher 1 and 2 phases respectively, significantly increased jejunum percentage of broilers $(\mathrm{P}<0.05)$, but had no significant effect on other carcass characteristics. Presumably, because of increases of percentage weight of heart, gizzard, ileum and jejunum of broilers feed on incremental levels of wheat-DDGS $(6,8,12$ and $14 \%)$ the carcass percentage decreased $(\mathrm{P}<0.05)$. On the other hand, the weight percentage reduction in broilers received diets contain $6,8,12$ and 14\% wheat-DDGS could be because of low amount of lysine and arginine and low digestibility of branched chain amino acids. The highest protein ratio of wheat-DDGS is from wheat (95\%) and the residual is from yeast (5\%) (Ingledew, 1993). So, it is expected that DDGS amino acids profile approximately equal to wheat amino acid profile. However, remarkable reduction in lysine (1.9 v.s $2.9 \mathrm{~g}$ lysine in $100 \mathrm{~g}$ protein) and arginine (3.8 v.s 5.1 in $100 \mathrm{~g}$ protein) in DDGS probably is affected broiler performance. Probably, these two amino acids are affected in maillard reaction during wheat DDGS production (Pederson et al., 2007). The increase of digestive organs such as gizzard, jejunum and ileum could be because of high fiber content of diets that is contain high level of DDGS.

The relative weight of digestive organs in broilers fed on diet contain high fiber significantly increased $(\mathrm{P}<0.05)$. According to results present study, Ibrahim et al (2008) showed that wheat-DDGS contain more soluble NSP $(35.61 \% \mathrm{DM})$ that is presumably hemicellulose. Spiehs et al (2002) reported that hemicellulose content in DDGS is higher than usual.

\section{Immune response}

The effect of different levels of wheat-DDGS on lymphoid organs and antibody titer against Avian Influenza and Newcastle Disease Viruses are summarized in Table 4. The results show that wheat-DDGS levels had no significant effect on immune responses of broilers. Barekatain et al (2013) showed that the necrotic enteritis in broilers fed on $20 \%$ sorghum with and without protease and zylanase enzymes improved; while, $\operatorname{IgA}$ and $\operatorname{IgM}$ titer of broilers challenged with necrotic enteritis in 21 and 35 days of age respectively, decreased $(\mathrm{P}<0.05)$. Min et al (2015) reported that super oxid dismutase and total antioxidant activity in blood serum of broilers in 21 days decreased by DDGS inclusion; so, IgA, IgG and MDA in blood serum increased.

Alizadeh et al (2016) reported that diets contain 10\% DDGS cause increase in cell mediated immune response, this increase represents the immune activity stimulation due to face to non-inflammatory antigens in broilers. Accordance with obtained results Gupta et al (2016) reported that 5, 7 and 10\% Rice-DDGS in broiler diet had significant effect on cellular mediate immunity and hemagglutination antigen. 
Conclusion The results showed that using incremental levels of wheat-DDGS till 7\% (3, 4, 6 and 7\% in starter, grower, finisher 1 and 2, respectively) had no significant effect on growth performance and immune responses. Therefore, above mentioned levels can be used to decrease diet price.

\section{References}

1) Alizadeh M, Rodriguez-Lecompte JC, Echeverry H, Crow GH, Slominski BA, 2016. Effect of yeast-derived products and distillers dried grains with solubles (DDGS) on anibody-mediated immune response and gene expression of pattern recognition receptors and cytokines in broiler chickens immunized with T-cell dependent antigens. Poultry Science 95: 823-833.

2) Barekatain MR, Antipatis C, Rodgers N, Walkden-Brown SW, Iji PA, 2013. Evaluation of high dietary inclusion of distillers dried grain with solubles and supplementation of protease and xylanase in the diets of broiler chickens under necrotic enteritis challenge. Poultry Science 92: 1579-1594.

3) Bolarinwa OA, Adeola O, 2012. Energy value of wheat, barely, and wheat dried distillers grains with soluble for broiler chickens determined using the regression method. Poultry Science 91: 1928-1935.

4) Cozannet P, Primot Y, Gady C, Meetayer JP, Lessive M, Skiba F, Noblet J, 2010. Energy value of wheat distillers grains with soluble for growing pigs and adult sows. Journal of Animal Science 88: 2382-2392.

5) Cozannet P, Primot Y, Gady C, Metayer JP, Callu P, Lessire M, Skiba F, Noblet J. 2010. Ileal digestibility of amino acids in wheat distillers dried grains with solubles for pigs. Animal Feed Science and Technology, 158: 177-186.

6) Gupta S, 2016. Feeding value of rice based dry distiller grains with soluble in white leghorn layers. Ph.D. Thesis submitted to IVRIDU. Izatngar, U.P.

7) Guney AC, Shim MY, Batal AB, Dale NM, Pesti GM, 2013. Effect of feeding low oil distillers dried grains with soluble on the performance of broilers. Poultry Science 92: 2070-2076.

8) Hetland H, Choct M, Svihus B, 2004. Role of insoluble nonstarch polysaccharides in poultry nutrition. World's Poultry Science Journal 60: 415-422.

9) Ibrahim Youssef MI, Westfahl C, Sunder A, Liebert F, Kamphues J, 2008. Evaluation of dried distillers' grains with solubles (DDGS) as a protein source for broilers. Archives of Animal Nutrition 62 (5): 404-414.

10) Ingledew WM. 1993. Yeast for production of fuel ethanol. In: The Yeast. 2 ed., Vol. 5. Yeast.

11) Lumpkins BS, Batal AB, Dale NM, 2004. Evaluation of distillers dried grains with soluble as a feed ingredient for broilers. Poultry Science 83: 1891-1896.

12) Min YN, Li LL, Liu SK, Zhang J, Gao YP, Liu FZ, 2015. Effects of dietary distillers dried grains with solubles (DDGS) on growth performance, oxidative stress, and immune function in broilers chickens. Journal of Applied Poultry Research 24: 23-29.

13) Olofintoye, OR, Bolu, SA, 2013. Effects of corn distillers dried grains on the performance and egg quality of laying hen. Animal Research International 10: 1665-1672.

14) Oryschak M, Korver D, Zuidhof M, Meng X, Beltranena E, 2010. Comparative feeding value of extruded and nonextruded wheat and corn distillers dried grains with solubles for broilers. Poultry Science 89: 2183-2196.

15) Pedersen C, Boersma MG, Stein HH, 2007. Digestibility of energy and phosphorus in ten samples of distillers dried grains with solubles fed to growing pigs. Journal of Animal Science 85: 1168-1176.

16) Shahryari M, Emadinia A, Davoodi A, Omrani M, Jafari M, Bahadoran R. 2019. Effect of fat sources in pellet form on performance and some immune responses of broiler chicks. Journal of Livestock Science 10: 59-65.

17) Shim MY, Pesti GM, Bakalli RI, Tillman PB, Payne RL, 2011. Evaluation of corn distillers dried grains with soluble as an alternative ingredient for broilers. Poultry Science 90(2): 369-376.

18) Spiehs MJ, Whitney MH, Shurson GC, 2002. Nutrient for distiller's dried grains with solubles produced from new ethanol plants in Minnesota and South Dakota. Journal of Animal Science 80: 2639-2645.

19) Thacker PA, Widyaratne GP, 2007. Nutritional value of diets containing graded levels of wheat distillers grains with solubles fed to broiler chicks. Journal of the Science of Food and Agriculture 87:1386-1390.

20) Waldroup PW, Owen JA, Ramsey BE, Whelchel DL. 1981. The use of high level of distillers dried grains with solubles in broiler diets. Poultry Science 60: 1479-1484.

21) Wang Z, Cerrate S, Coto C, Yan F, Waldroup PW. 2008. Evaluation of high levels of distillers dried grains with solubles (DDGS) in broiler diets. International Journal of Poultry Science 7:990-996.

22) Wen Jiang, Licong, Z. and Anshan, S, 2013. The effect of vitamin E on laying performance and egg quality in laying hens fed corn dried distillers grains with soluble. Poultry Science 92: 2956-2964.

23) Widyaratne GP, Zijlstra RT, 2007. Nutritional value of wheat and corn distillers dried grain with solubles: digestibility and digestible contents of energy, amino acids and phosphorous, nutrient excretion and growth performance of grower-finisher pigs. Canadian Journal of Animal Science, 87(1): 103-114.

24) Zhang Y, Shan A, Jiang W, Bi C, Li Z, 2013. The effect of vitamin E on growth performance and meat quality in broilers given diets containing distillers' dried grain with solubles (DDGS). British Poultry Science 54(1): 138-143. 